\title{
Business Strategy for PT Finansindo Mikro Facing Competition in Microfinance Business
}

\author{
Nadirah Sudarto ${ }^{*}$, Alibasjah Inggriantara ${ }^{2}$ \\ ${ }^{I}$ MBA Student, Department of Business and Management, The School of Business and Management ITB, \\ Jakarta, Indonesia \\ ${ }^{2}$ Research/Faculty Member, Department of Business and Management, The School of Business and Management \\ ITB, Jakarta, Indonesia \\ *Corresponding author: nadirah_sudarto@sbm-itb.ac.id
}

\begin{abstract}
Financial technology or fintech, has developed rapidly and made matters easier for storing, borrowing or investing online or with mobile devices. The competition can be seen through peer -to-peer (P2P) lender accounts, which have increased from year to year. Finansindo is engaged in micro-business as a P2P that targets women entrepreneurs who cannot access conventional banks or are not bankable. such as banks and microfinance institutions (MFIs). The External and internal environment will be analyzed to understand current business conditions. Analysis of the external environment contains PEST, industry forces and competitor analysis. Internal environment includes 7P marketing mix analysis and STP analysis. SWOT Analysis and Ansoff Matrix are used to obtain three strategic choices, namely: market development, product development, and market development, together with product development. Based on the analysis, the chosen strategy is market development. Product development is less attractive due to regulations limiting P2P. Market development and joint product development are not attractive due to regulation and limited resources. In conclusion, Finansindo recommends focusing on market development, which offers the same target but in other geographical areas. Adjusting to the previous segment and with relatively high ceiling considerations, Finansindo is recommended to operate in Aceh, North Sumatra, and Riau.
\end{abstract}

Keywords: Ansoff matrix, Fintech, Market development, Microloan.

\section{Introduction}

Financial technology, or fintech, is rapidly developing and making it easier to save, borrow or invest online or with a mobile device. According to Statista.com, the transaction amount in Fintech keeps increasing year to year. In 2019, the transaction amount reached USD 32 billion and predicted to achieve USD 38 billion in 2020. It is also analyzed that the competition in the banking industry has become tighter since the presence of Fintech (Medcom, 2020). The competition shows through number of $\mathrm{P} 2 \mathrm{P}$ lender account which escalated $192 \%$, borrower account $325 \%$ and disbursed amount $259 \%$ from Statistik Fintech Lending 2019 by OJK (Statista, 2019).

OJK's Director of Regulations, Licensing, and Oversight of Fintech Hendriks Passa hopes the Fintech P2P Lending will provide loans to not-bankable market and SMEs. He considered banks to have limitations in channelling funding to the micro sector, which is caused by a less flexible business model. Therefore, Fintech has more flexibility to target microbusinesses and help provide access to sales and marketing (Jawa Pos News Network, 2020). However, Fintech and other financial institution have to monitor and maintain the level of the Non-Performing (NPL) rate must be monitored. This can be seen in deflation of Tingkat Keberhasilan (TKB90) below. In beginning 2019, TKB90 was $98 \%$ and reached $96 \%$ in November 2019 (Otoritas Jasa Keuangan, 2019).

One of P2P which targets not bankable people and micro businesses is Finansindo. PT Finansindo Mikro (Finansindo) is peer-to-peer $(\mathrm{P} 2 \mathrm{P})$ lending that helps lenders connect with rural micro-entrepreneurs through loans. Finansindo was a cooperative and transformed into a fintech company in 2016 (Finansindo, 2016). Finansindo must compete with other microloan providers, such as the Bank and Micro Finance Institution (MFI). Finansindo must compete to increase its growth and reduce the NPL. Therefore, Objectives of the research are:

1. To analyze the current business conditions of Finansindo.

2. To propose business strategy in Finansindo.

3. To recommend implementation plans for Finansindo based on defined strategies.

\section{Literature Review}

\section{A. PEST Analysis}

PEST Analysis consists of Political, Economic, Social and Technology. The political factor is including Government regulations and legal. PES is a business measurement tool to understand the position, potential and direction for a business. A PEST analysis is. PEST analysis is essential for strategic management (Gupta, 2013). Information from PEST should be included in every business plan, in addition to a SWOT analysis, as it is part of risk management and strategy design (Post, 2018). 


\section{B. Industry Forces}

A corporation needs to assess the importance to its success of each of six forces: the threat of new entrants, rivalry among existing firms, the threat of substitute products or services, bargaining power of buyers, bargaining power of suppliers, and power of other stakeholders. Even Porter particularly introduced five forces, the sixth force - other stakeholders - is added to reflect the influence that governments, local communities, and other groups from the task environment operate over industry activities (Wheelen T. 1. et al. 2010)

\section{Competitor Analysis}

Competitor analysis developed into two stages for the following reasons. Firstly, there are two separate tasks to be performed: competitor identification and competitor analysis. Competitor identification is required to avoid competitive blind spots. Secondly, these two tasks require two separate functions. Competitor identification is essentially a categorization task that involves classifying firms on the basis of relevant similarities. In contrast, competitor analysis is an evaluative task that goes beyond mere classification to compare rivals on the basis of the relevant dimension (Bergen \& Peteraf, 2002)

\section{STP Analysis}

The major segmentation variables geographic, demographic, psychographic, and behavioral segmentation We can target markets at four main levels: mass, multiple segments, single (or niche) segment, and individuals (Kotler, 2015). Targeting is essential for marketing planning, implementation and control (Kotler, 2011).

\section{E. 7P of the Marketing Mix}

European academics suggest to use of the 7Ps framework (or at any rate, modifications of the 4Ps mix). 7Ps are Product Price Place Promotion Participants Physical Evidence and Process (Rafuq, 1995). The study showed what aspects of 7Ps were to identify the strategies and play an essential role in development. By using the 7 Ps and strategic planning, an institution will be able to create a coherent framework to understand and analysis students" needs and attitudes and modify its policy accordingly (Samani, et al., 2018)

\section{F. Ansoff Model}

Ansoff model is used for strategic marketing planning to look at opportunities to grow revenue for a business through developing new products and services or "tapping into" new markets. This model is used to evaluate opportunities for companies to increase their sales through showing alternative combinations for new markets (i.e. customer segments and geographical locations) against products and services offering four strategies as shown to retain its relative position, a business firm must go through continuous growth and change (Ansoff, 1957).

\section{G. Plus-Minus-Interesting (PMI)}

According to former research, PMI is useful to offer imaginative alternatives to the solution of conflicts than negotiation or compromise. The PMI knowledge elicitation tool consists of two modules, the first to gather the information, the second to analyze it. The first module can be said to be a prototype elicitation tool; the second module is still in its very early stages. Bono's thinking tool PMI is suitable for an advicegiving system (Portmann and Easterbrook 1992). PMI method is used to generate ideas about a question or a problem and it obliges to consider all ideas (Sharma \& Priyamvada, 2017).

\section{H. Diamond Strategy}

According to (Hambrick \& Fredrickson, 2001), Strategy is required to achieve the objective and to allocate time and resources. Strategy addresses how the business intends to engage the internal organizational arrangements to play part in strategy.

\section{Methodology and Data Collection}

\section{A. Methodology}

This research will focus on actual and real conditions facing issues and challenges in PT. Finansindo Mikro. Qualitative research used to observe and gather data on what, how and when the issue occurs. In this case, to increase the number of outstanding in PT. Finansindo Mikro. The qualitative research method used in this research, including observing and interview with related stakeholder.

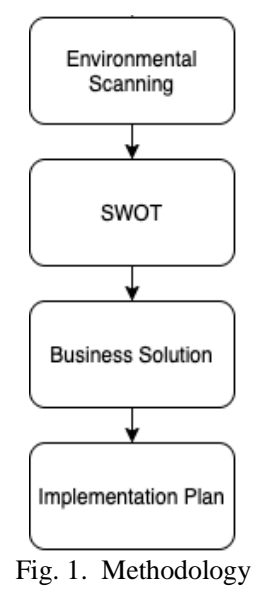

\section{B. Data Collection}

The data used in this study are primary data and secondary data. Secondary data used include books, literature, company policy and company reports. Primary data also support the study. Primary data includes data from the database, which is re-processed by the author, observation and interview. This study conduct interview on related stakeholders, including customers, C-level and VP level.

Interview to customer is conducted in order to get better understanding of customer condition. The interview is conducted to two borrowers which already in Finansindo for more than 10 years with loan ticket size below and above Rp. 6.000 .000 . 


\section{Result and Analysis}

\section{A. SWOT Analysis}

\begin{tabular}{|c|c|c|c|}
\hline \multicolumn{4}{|c|}{$\begin{array}{c}\text { Table } 1 \\
\text { SWOT analysis }\end{array}$} \\
\hline \multicolumn{2}{|c|}{ Strength } & \multicolumn{2}{|c|}{ Weaknesses } \\
\hline $\begin{array}{l}\text { S1. } \\
\text { S2. } \\
\text { S3. } \\
\text { S4. }\end{array}$ & $\begin{array}{l}\text { The only technology-based micro loan provider } \\
\text { Transparency in pricing } \\
\text { Off balance sheet lending } \\
\text { Research and development }\end{array}$ & $\begin{array}{l}\text { W1. } \\
\text { w2. }\end{array}$ & $\begin{array}{l}\text { Inflexible payment terms (only } 50 \text { weeks) } \\
\text { Only have oneproduct; group lending }\end{array}$ \\
\hline \multicolumn{2}{|c|}{ Opportunities } & \multicolumn{2}{|c|}{ Threats } \\
\hline $\begin{array}{l}01 . \\
02 . \\
03 .\end{array}$ & $\begin{array}{l}\text { High number of pre-prosperities } \\
\text { Most competitor have saving product } \\
\text { Most competitor have individual loan product }\end{array}$ & & $\begin{array}{l}\text { Local communities' power (CSOs) } \\
\text { Borrower characteristic. } \\
\text { Changes in regulation } \\
\text { Level of crime in the area }\end{array}$ \\
\hline
\end{tabular}

Based on SWOT, there are two recommended alternatives; They are Market Development and Product Development. The table for selecting strategy alternatives is shown in. In addition to the result, Finansindo is currently preparing both Market Development and Product Development at the same time. Therefore, the alternatives offered are:

1. Market Development

2. Product Development

3. Market Development and Product Development

\section{B. PMI Analysis}

\begin{tabular}{|c|c|c|c|c|}
\hline & $\begin{array}{c}\text { Market } \\
\text { Penetration }\end{array}$ & $\begin{array}{c}\text { Market } \\
\text { Developm } \\
\text { ent }\end{array}$ & $\begin{array}{c}\text { Product } \\
\text { Developen } \\
\text { ent }\end{array}$ & $\begin{array}{c}\text { Diversifi } \\
\text { cation }\end{array}$ \\
\hline \multicolumn{5}{|l|}{ Strengths: } \\
\hline $\begin{array}{l}\text { S1. The only technology-based } \\
\text { micro loan provider }\end{array}$ & 4 & 4 & 3 & 3 \\
\hline S2. Transparency in pricing & 4 & 4 & 1 & 1 \\
\hline S3. Off balance sheet lending & 4 & 4 & 1 & 1 \\
\hline S4. Research and Developenent & 1 & 4 & 4 & 2 \\
\hline \multicolumn{5}{|l|}{ Weaknesses: } \\
\hline $\begin{array}{l}\text { W1. Inflexible payment terms (only } \\
50 \text { weeks) }\end{array}$ & 1 & 1 & 4 & 4 \\
\hline $\begin{array}{l}\text { W2. Only have loan product; group } \\
\text { lending }\end{array}$ & 1 & 1 & 4 & 4 \\
\hline \multicolumn{5}{|l|}{ Opportunities: } \\
\hline $\begin{array}{l}\text { 01. High number of pro-prosperities } \\
\text { in other area }\end{array}$ & 1 & 4 & 3 & 4 \\
\hline $\begin{array}{l}\text { O2. Most competitor have saving } \\
\text { prodact }\end{array}$ & 1 & 1 & 4 & 2 \\
\hline $\begin{array}{l}\text { 03. Most competitor have individal } \\
\text { loan product }\end{array}$ & 1 & 1 & 4 & 2 \\
\hline \multicolumn{5}{|l|}{ Threats: } \\
\hline T1. Local communities' power & 1 & 4 & 1 & 3 \\
\hline T2. Borrower characteristic. & 1 & 4 & 1 & 3 \\
\hline T3. Changes in regulation & 4 & 4 & 1 & 1 \\
\hline T4. Possibility of crime in the area & 1 & 1 & 4 & 2 \\
\hline Total & 25 & 37 & 35 & 32 \\
\hline \multicolumn{5}{|l|}{ Rating score: } \\
\hline \multicolumn{5}{|l|}{$4-$ very attractive } \\
\hline \multicolumn{5}{|l|}{ 3- attractive } \\
\hline \multicolumn{5}{|l|}{2 - somerahat attractive } \\
\hline 1- less attractive & & & & \\
\hline
\end{tabular}

Based on the results in PMI above shows that the most attractive strategy is Market Development. Market development has a significant positive relationship with the firm's growth by selling your on-hand products or services to fresh markets. Segmentation variables to consider are Geographical reach language, other industries and different use for your product are different growth options through market development. Markets can be explored inside of the current market's segments (Hussain, et al., 2017). Market development is offering existing products to new markets. There are several strategies of Market Development:

- $\quad$ Same Target Group, New Geographic Area

- New Target Group, Same Geographic Area

- New Target Group, New Geographic Area

In order to overcome the case of local community (CSOs/NGOs) intervention and to increase the market share in Indonesia, Finansindo is recommended to target the same group in other geographic area. Further, the key is adjusting the marketing program to recognize customer differences. The significant segmentation variables are geographic, demographic, psychographic, and behavioral segmentation (Kotler \& Keller, 2016). Company needs to adapt its present product line (generally with some modification in the product characteristics) to new missions (Ansoff, 1957), therefore the company needs some adjustment in terms of STP and pricing.

Finansindo has two segments as their targets approached Java and non-Java, therefore the level of segmentation is Multiple Segment. Further, Finansindo needs to adjust the marketing program to recognize customer differences. By using existing segmentation is done targeting the new geographic. The chosen provinces are based on the existing target market.

The proposed target market is Aceh, Sumatera Utara, and Riau. To determine the provinces that will be the target market then authors do a comparison between each province and choose the provinces that have a lot of target markets. Finally, proposed provinces are Aceh, Sumatera and Riau of Indonesia regarding the demographic and geographic variables as shown. In addition to this, Finansindo is recommended considering the number of MFI in the targeted market.

Positioning is the act of designing a company's offering and image to occupy a distinctive place in the minds of the target market. Finansindo position is providing productive micro loans for not bankable and lower-class females with transparent pricing to reduce poverty. Implementation planning largely determines project success. To implement a plan properly, company set clear goals and clear priorities. Priorities are generally based on due dates, client needs, financial concerns, worker needs or logistics. Deadlines help guarantee the implementation of a plan with realistic due dates.

\section{Conclusion}

This study concludes that based on the internal and external condition of the company, Finansindo just has one core loan product, that is group lending. Finansindo's competitors are the conventional MFIs; both bank and non-bank financial institutions. This makes Finansindo as the only P2P who offer microloans. However, most of these conventional MFIs have more diversified products offered, like individual loans and savings. Externally, Finansindo threatened the existence of local communities' (CSOs/NGOs) intervention, borrower's characteristics, regulation, and probability of crimes.

For boosting the growth, Finansindo has three options that fit based on its SWOT analysis. Further analysis of Finansindo positioning resulting in market development as the strategy 
with most advantages. The chosen strategy for Finansindo's current condition is targeting the same segment but in different areas. Based on its performance in the current segment, Finansindo is recommended to expand the operation within the operating island due to operating cost consideration.

\section{References}

[1] Ansoff, H. I, "Strategies for Diversification". Harvard Business Review, 35(5), 113-124. 1957.

[2] Bergen, M. \& Peteraf, M. A. "Competitor Identification and Competitor Analysis: A Broad Based Managerial Approach" Managerial and Decision Economics, 23, p. 157-169. 2002.

[3] Gupta, A, "Environment \& PEST Analysis: An Approach to External Business Environment". International Journal of Modern Social Sciences, 2(1): 34-43. 2013.

[4] Hambrick, D. C., and Fredrickson, J. W," Are you sure you have a strategy?" Academy of Management Executive, November.15(4). 2001.

[5] Hussain, Sajjad, and Khattak, Jamshed \& Rizwan, Arshad \& Latif, Adnan, "ANSOFF matrix, environment, and growth-an interactive triangle." Management and Administrative Sciences Review. 2. 196-206. 2013.

[6] Jawa Pos News Network. Fintech P2P Lending Berperan Penting untuk Kemajuan UMKM. (PT. Jaringan Pemberitaan Nusantara Negeriku) Available from: https://www.jpnn.com/news/fintech-p2p-lending-berperan-pentinguntuk-kemajuan-umkm [accessed on March 2020]. 2020.

[7] Kotler, P., and Keller K, "Marketing management" 15th global edition. Harlow. 2015.
[8] Kotler, P. Philip Kotler's. "Contributions to Marketing Theory and Practice", Review of Marketing Research, 87-120, 2011.

[9] Medcom. (2020). Indef: Persaingan Bank dan Fintek Kian Ketat. Retrieved April 5, 2020.

[10] Otoritas Jasa Keuangan. Statistik Fintech Lending. Retrieved April 5, 2020 ,

https://www.ojk.go.id/id/kanal/iknb/data-danstatistik/fintech/Pages/Statistik-Fintech-Lending-Periode-Desember2019.aspx. 2019.

[11] Portmann, M. M., and Easterbrook, S. M. "PMI: Knowledge elicitation and De Bono's thinking tools", Proceedings of the 6th European knowledge acquisition workshop on Current developments in knowledge acquisition, 264-282, 1992.

[12] Post, J., What Is a PEST Analysis? [Online] Available at: https://www.businessnewsdaily.com/5512-pest-analysis-definitionexamples-templates.html [April 2020]

[13] Samani, F. S., Touroujeni, S. M. H., and Vahide, S. "Investigating the Role of Marketing Mix Elements (7Ps) and Strategic Planning in Development of Iranian English Language Departments". International Journal on Studies in English Language and Literature (IJSELL), 5, 4(4), 50-59. 2018.

[14] Sharma, H. L. and Priyamavda. PMI (Plus-Minus-Interesting): A creative thinking strategy to foster critical thinking. 2017.

[15] Statista. FinTech Report 2019. Retrieved April 5, 2020, from https://www.statista.com/study/44525/fintech-report/. 2019.

[16] Statista. FinTech Report 2019. Retrieved April 5, 2020, from https://www.statista.com/study/44525/fintech-report/. 2019.

[17] Wheelen, T. L., Hunger, J. D., Hoffman, A. N., and Bamford, C. E. Strategic management and business policy. Upper Saddle River, NJ: Prentice Hall. 2010. 